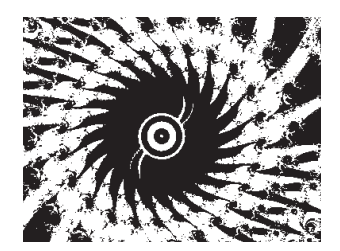

doi:10.5559/di.21.4.10

\title{
OSNOVNE ZNAČAJKE PRESUDA JUGOSLAVENSKIH KOMUNISTIČKIH VOJNIH SUDOVA U HRVATSKOJ 1944. I 1945. GODINE
}

Josip JURČEVIĆ

Institut društvenih znanosti Ivo Pilar, Zagreb

UDK: 344.3(497.5)"1944/1945"

Prethodno priopćenje

Primljeno: 17. 9. 2012.

Rad je uglavnom nastao na temeliu istraživanja više tisuća sačuvanih presuda jugoslavenskih komunističkih vojnih sudova. Ta povijesna građa do sada je bila nekorištena ili malo korištena u znanstvenim istraživanjima. Središnja istraživačka tema rada jesu osnovne značajke presuda jugoslavenskih komunističkih vojnih sudova u Hrvatskoj 1944. i 1945. godine. Najprije je prikazana osnovna struktura presuda. Potom su detaljno analizirane karakteristične pojedinačne presude s raznih područja Hrvatske, a u zaključku su navedene glavne zbirne značajke sačuvanih presuda. I ovo je istraživanje upečatlijivo potvrdilo da su jugoslavenski vojni sudovi u Hrvatskoj bili revolucionarni sudovi te da su bili dio represivnoga sustava kojim je Komunistička partija Jugoslavije dovršavala proces uspostavlianja svoje totalitarne vlasti. Iz konkretnih presuda jasno se vidi da su se procesi pred vojnim sudovima odvijali prema ideološkim kriterijima i protivno pravnim standardima. Sudski su procesi bili brzi, a kazne nemilosrdne. Krivnja nije dokazivana na temelju konkretnih činjenica, a iskazi i argumenti optuženih odbacivani su bez razmatranja, uz uvredlijive i ponižavajuće konstatacije o optuženima. lako je Uredba o vojnim sudovima za optužene osobe propisivala pravo na branitelja, to pravo nije ostvarila ni jedna od približno 5200 osuđenih osoba za koje postoje sačuvane presude, među kojima nema ni jedne oslobađajuće.

Ključne riječi: presude jugoslavenskih komunističkih vojnih sudova, komunistička represija u Hrvatskoj, revolucionarni sudovi, totalitarizam, Uredba o vojnim sudovima 
Iako u pismohranama postoji dostupna izvorna povijesna građa o jugoslavenskim komunističkim sudovima koji su djelovali tijekom Drugoga svjetskoga rata i neposrednoga poraća u Hrvatskoj (vojni sudovi, sudovi za zaštitu nacionalne časti, narodni sudovi), ova važna tema veoma je slabo znanstveno-historiografski istražena, a druge društveno-humanističke znanosti nisu je još otvorile ni na koji način. Znanja o ustrojavanju i djelovanju komunističkoga pravosuđa posebno su važna za razumijevanje revolucionarnoga nasilja, kao bitne odrednice načina uspostavljanja komunističke vlasti, te potom provođenja diktature proletarijata $\mathrm{u}$ totalitarnom komunističkom poretku.

Komunistička partija Jugoslavije je i prije rata bila dio organiziranoga međunarodnoga komunističkoga kruga, koji je bio sljedbenik svjetonazorske i političke doktrine koju su oblikovali tzv. klasici marksizma (v. Vranicki, 1987.). Prema toj doktrini, komunisti "izjavljuju otvoreno da se njihovi ciljevi mogu postići samo nasilnim rušenjem čitavog dosadašnjeg društvenog poretka" i neka "vladajuće klase drhte pred komunističkom revolucijom" (Marx i Engels, 1973., 53) No revolucionarno preuzimanje vlasti nije se smatralo završetkom nasilja, nego je to bio početak postrevolucionarnoga nasilja - "diktature proletarijata" - koju je V. I. Lenjin opisao kao "najžešći i najnemilosrdniji rat nove klase protiv moćnijeg neprijatelja, protiv buržoazije, čiji je otpor udesetorostručen njenim obaranjem ... diktatura proletarijata je nužna i pobjeda nad buržoazijom nije moguća bez dugog, upornog, ogorčenog rata na život i smrt" (Lenjin, 1973., 121).

Na temelju ovih općih idejnih određenja istraživani su filozofijski i politologijski aspekti komunizma kao posebne vrste totalitarizma (v. Arendt, 1996.; Puhovski, 1990.) te razmjeri i posljedice represivne upravljačke prakse komunističkih režima u nizu europskih i izvaneuropskih zemalja (v. Courtois i sur., 1999.).

Pri kraju Drugoga svjetskoga rata i u neposrednom poraću, partija je revolucionarnim nasiljem i diktaturom proletarijata vodila "najžešći i najnemilosrdniji rat" protiv osoba, organizacija, ideja i simbola koji su mogli remetiti dovršetak uspostavljanja i opstajanja totalitarne vlasti KPJ u Jugoslaviji (v. Jurčević, 2005.).

Činjenicu da je Jugoslavija postala tipična totalitarna komunistička država nedvojbeno su - ali s apologetskim pristupom i terminologijom - potvrđivali i istaknuti jugoslavenski komunistički povjesničari. Primjerice, povjesničar iz Srbije je zaključio: "Jednopartijski sistem revolucionarne demokratije imao je po završetku rata sve elemente diktature proletarijata, 
DRUŠ. ISTRAŽ. ZAGREB GOD. 21 (2012), BR. 4 (118)

STR. 1007-1026

JURČEVIĆ, J.: OSNOVNE ZNAČAJKE... koju je u ime radničke klase ostvarivala KPJ kao njena avangarda ... KPJ je ispunjavala celokupan politički prostor, neposredno odlučivala o pravcu razvitka, ostvarivala svoju volju posredstvom državnog aparata, zakonodavstva i masovnih političkih organizama, čiji su programi izražavali partijski program" (Petranović, 1988., II, 481).

Na isti je način zaključivao i povjesničar iz Hrvatske: "... rukovodstvo KPJ imalo je gotovo neograničenu mogućnost da utvrđuje politiku društvenog razvoja Jugoslavije. U povijesti se rijetko stječe tako čvrsta i nepodijeljena vlast u rukama jednog revolucionarnog pokreta; svi organi vlasti - zakonodavni i izvršni, vojska i milicija, sigurnost i sudstvo - bili su bez izuzetka čvrsto u rukama KPJ" (Bilandžić, 1985., 101-102).

Vojni sudovi imali su posebnu ulogu u najopsežnijoj represiji koju je od sredine 1944. do kraja ljeta 1945. provodila struktura vlasti pod nadzorom KPJ. O toj su temi do sada objavljena samo dva znanstvena rada (Jurčević i Ivanda, 2006.a, 2006.b), u kojima je istražen tijek procesa ustrojavanja sustava vojnih sudova tijekom Drugoga svjetskog rata i neposrednoga poraća te koncepcija njihova djelovanja kao dijela represivnoga sustava jugoslavenskoga komunističkog režima u Hrvatskoj.

Istraživanja (objavljena u dva rada) pokazala su da je ustrojavanje vojnih sudova, kao i cjelokupnoga sustava vlasti pod nadzorom KPJ, započelo 1941. godine, i to tako da se krenulo od najosnovnijih početaka te se nastavilo oblikovati u smjeru koji se bitno razlikovao od dotadašnjih civilizacijsko-građanskih iskustava. Tako, u početnom razdoblju ustrojavanja pravosuđa pod nadzorom KPJ, nisu postojala ni pravosudna tijela ni propisi, a to su kasnije jasno opisivali i tadašnji akteri: "... sudsku funkciju u pojedinim slučajevima vrši neposredno sam narod, na masovnom zboru određenog mjesta. Takvim suđenjem obično je rukovodio komandant partizanskog odreda ili neki istaknuti pripadnik narodnooslobodilačkog pokreta toga kraja. Postupak je bio potpuno neformalan, a sudska se presuda odmah izvršavala" (Geršković, 1948., XXVI).

Posebno vrijedna povijesna građa jesu presude jugoslavenskih komunističkih vojnih sudova iz 1944. i 1945. godine, koje su sačuvane u Hrvatskom državnom arhivu (HDA). Iz numeracije presuda i drugih dokumenata vidi se da je većina presuda uništena ili nekamo sklonjena (v. Jurčević, 2005., 135-143). No zbog intenzivnoga djelovanja vojnih sudova, sačuvan broj presuda u HDA - približno 3500 presuda ili njihovih dispozitivnih dijelova, s raznih područja Hrvatske (v. Jurčević i Ivanda, 2006.b) - dostatan je za relevantna i raznovrsna historiografska i druga istraživanja.

O tadašnjim suđenjima pred vojnim sudovima, proble$\mathrm{mu}$ (ne)sačuvanosti presuda i nekim razlozima neistraženosti 
DRUŠ. ISTRAŽ. ZAGREB GOD. 21 (2012) BR. 4 (118),

STR. 1007-1026

JURČEVIĆ, J. OSNOVNE ZNAČAJKE.. ove teme na poseban način upućuje i to što su tadašnji glavni pravosudni i vojno-politički akteri izbjegavali i desetljećima kasnije o tome javno razgovarati, ili se u njihovim knjigama i knjigama o njima (memoari, biografije itd.) preko te teme prelazi apologetski, ili brzo i površno, uz redovito umanjivanje i prikrivanje stvarnih događanja i njihove uloge u njima (v. Hrnčević, 1984.; Blažević, 1976.; Vukmanović, 1971.; Mujadžević, 2011.). U tom su smislu posebno zanimljiva brojna i javna očitovanja o presudi vojnoga suda (iz lipnja 1945. godine) protiv Mile Budaka, iako izvorna presuda još nije pronađena (Sagrak, 2006.).

Ovaj se rad temelji prije svega na analizi i uspoređivanju inkriminacija u presudama vojnih sudova s obrazloženjima presuda, jer se na taj način može pouzdano prosuđivati o (ne)utemeljenosti krivnje i kazne koju je izrekao sud. A prevladavajući pravosudni pristup u većini je presuda bitan za nastanak objektivnih saznanja o pravosudnoj kakvoći cjelokupne sudske prakse te o kakvoći širih političkih i društvenih okolnosti. Odabrane presude vojnih sudova, koje su iskorištene $\mathrm{u}$ ovome radu, predstavljaju reprezentativan uzorak $\mathrm{s}$ raznih područja Hrvatske, a pravosudnom kakvoćom koju sadrže također su tipične za gotovo sve sačuvane presude sa svih područja Hrvatske. Ostali primarni povijesni izvori i literatura u radu upotrijebljeni su kako bi se kontekstualizirala osnovna istraživačka tema te pridonijelo temeljitijem razumijevanju represije koju je komunistički režim provodio u Hrvatskoj 1944. i 1945. godine. Isto tako, rad bi trebao pridonijeti većoj zainteresiranosti historiografije za daljnja istraživanja te potaknuti ostale društvene znanosti da se uključe $u$ istraživanja ove teme.

\section{ZBIRNE ZNAČAJKE PRESUDA}

Prema dostupnim podacima - koji predstavljaju tek manji dio presuda koje su izrečene - jugoslavenski komunistički vojni sudovi su u približno godinu dana (od jeseni 1944. do jeseni 1945. godine) na teritoriju Hrvatske osudili približno 5200 osoba, a od toga je nešto više od 1500 osoba osuđeno na smrt strijeljanjem ili vješanjem (v. Jurčević i Ivanda, 2006.b). Osim toga, važan je podatak kako je najveći dio sačuvanih presuda nastao od lipnja do kolovoza 1945. godine, s tim što je unutar toga uvjerljivo najzastupljeniji mjesec srpanj.

Najveći dio sačuvanih presuda vojnih sudova koje su izrečene i prije kraja rata (uključujući i presude koje su na pojedinim hrvatskim područjima izrečene u završnim mjesecima 1944. godine) jesu presude koje su izrečene pošto su vojne i/ili političke strukture pod nadzorom KPJ trajno preuzele vlast na tim područjima. Odnosno, na tim područjima više ni- 
DRUŠ. ISTRAŽ. ZAGREB GOD. 21 (2012),

BR. $4(118)$

STR. 1007-1026

JURČEVIĆ, J.:

OSNOVNE ZNAČAJKE... je bilo ni ratnih sukoba ni nekomunističkih vlasti. Primjerice, već od rujna 1944. jugoslavenska komunistička vojska trajno je zauzela teritorij i uspostavila svoju vlast u južnim primorskim dijelovima Hrvatske (Dalmacija), a Dubrovnik je zauzet "sa zakašnjenjem" - 18. listopada 1944. godine.

Temeljita reorganizacija institucije vojnih sudova provedena je Uredbom o vojnim sudovima, koju je 24. svibnja 1944. uime Vrhovnoga štaba potpisao Josip Broz Tito (HDA, fond [f.] Odjeljenje zaštite naroda [OZN-a], kutija [k.] 1, omot [o.] 3, "Uredba o vojnim sudovima" - u daljnjem tekstu: - Uredba). Desetak dana prije donošenja Uredbe, odlukom J. B. Tita, osnovana je OZN-a kao glavni nositelj svekolike komunističke represije do kraja rata i u poraću, te je OZN-a na razne načine ostvarivala nadmoć nad gotovo svim tijelima komunističke vlasti (v. Jurčević, 2005., 239-292). Niz dokumenata pokazuje da su i vojni sudovi u svojem djelovanju bili u svemu podređeni OZN-i, iako to nije bilo formalno predviđeno Uredbom o vojnim sudovima (v. Jurčević i Ivanda, 2006.a, 906-908). Dokumenti pokazuju da su vojni sudovi čak i sami tražili da im OZN-a s optuženim osobama dostavlja i "mišljenje kakova bi kazna odnosno rješenje najviše koristilo interesima NOB" (HDA, f. OZN-a, k. 10, o. 3, "Broj: 100/1944, 24. kolovoz 1944", arh. str. 86).

Uredbom su ukinuti dotadašnji vojni sudovi te je određeno da će nadalje "vojno-sudsku vlast" vršiti vojni sudovi korpusa i vojni sudovi korpusnih vojnih oblasti te Viši vojni sud (Uredba, čl. 1). Vojni sudovi korpusa i vojni sudovi korpusnih vojnih oblasti bili su sudovi iste razine, ali su se međusobno isprepletali prema ovlastima, strukturi i kadrovima, pa se i na taj način osiguravala jednoobraznost njihova djelovanja.

Uredbom je također temeljito, cjelovito i detaljno regulirano djelovanje vojnih sudova. Iz sačuvanih presuda proizlazi da su vojni sudovi potom petnaest mjeseci bili glavno pravosudno sredstvo za provođenje široke sudske represije nad pretežito civilnim osobama koje su bile nepoželjne komunističkoj vlasti.

U svezi s tim treba posebno naglasiti da je Uredba detaljno odredila vrste "ratnih zločinaca" te "narodnih neprijatelja" (Uredba, čl. 13 i 14). Zapravo, riječ je o široko postavljenom nabrajanju niza djela i djelatnosti (npr. "funkcioneri terorističkog aparata", "svi oni koji su u službi neprijatelja ma u kom vidu - kao špijuni, dostavljači, kuriri, agitatori i slično", "svi oni koji su izdali narodnu borbu", "svi oni koji se odmetnu od narodne vlasti" itd.; Uredba, čl. 13 i 14), prema kojima su vojnim sudovima omogućena suđenja civilnim osobama, praktički bez ograničenja. 
DRUŠ. ISTRAŽ. ZAGREB GOD. 21 (2012) BR. $4(118)$

STR. 1007-1026

JURČEVIĆ, J.

OSNOVNE ŻNAČAJKE..
Uredba je bila na snazi do 31. kolovoza 1945. godine, kada je na snagu stupio Zakon o uređenju i nadležnosti vojnih sudova (Službeni list, br. 65, 31. kolovoza 1945.), koji je - u odnosu na Uredbu - znatno suzio ovlasti vojnih sudova. Inkriminacije koje su se u Uredbi odnosile na "ratne zločince" i "narodne neprijatelje" premještene su (u još razrađenijem obliku) u Zakon o krivičnim djelima protiv države (Službeni list, br. 66, 1. rujna 1945.).

Najvažnije je što je ovaj Zakon propisao da civilnim osobama - koje se optužuje da su "ratni zločinci" i "narodni neprijatelji" - dalje sude "narodni sudovi", osim "u naročito važnim slučajevima" i slučajevima "državnog značaja", u kojima sude vojna vijeća zemaljskih vrhovnih sudova ili vojno vijeće saveznoga Vrhovnoga suda (Zakon o krivičnim djelima protiv države, čl. 14). Prema tome, tek od početka rujna 1945. vojni sudovi prestali su biti nadležni za procesuiranje civilnih osoba za djela koja su pripadala odredbama "ratnog zločina" $\mathrm{i}$ "narodnog neprijatelja" (detaljnije o svemu v. Jurčević i Ivanda, 2006.a).

Uredba je odredila kako se u uvodnom dijelu presude "mora" nalaziti, uz ostalo, prezime i ime "branitelja ako ga ima" (Uredba, čl. 28, st. 1), a prije toga je određeno: "U slučaju da optuženi nije sposoban da se sam brani, sud će mu dozvoliti da izabere branitelja, ili će mu ga sam odrediti" (Uredba, čl. 23).

Međutim, ni u jednoj sačuvanoj presudi nema imena branitelja niti se bilo gdje u presudama naznačuje nazočnost branitelja ili bilo koji drugi trag koji bi upućivao na mogućnost postojanja branitelja prije, $\mathrm{u}$ tijeku ili nakon procesa pred vojnim sudovima. Osim toga, čak se ni u jednoj presudi ne navodi je li tko od optuženih tražio branitelja ili je li sud komu nudio branitelja ili je li sud razmatrao pitanje potrebe nazočnosti branitelja. Ni u jednoj se presudi ne nalazi barem konstatacija kako je optuženi sposoban da se sam brani ili sl.

Stoga, budući je Uredbom bilo propisano pravo optuženika na branitelja, a ni $u$ jednoj sačuvanoj presudi nema ni spomena o branitelju, nedvojbeno se može zaključiti kako je sudska praksa jugoslavenskih vojnih sudova u Hrvatskoj nametnula čvrsto pravilo, prema kojem optužene osobe nemaju pravo na branitelja, a time praktički ni na obranu.

U potporu obaju zaključaka govori i odredba Uredbe koja kaže da istražitelj (koji zastupa optužbu) "prikuplja dokazni materijal kako optužbe tako i obrane" (Uredba, čl. 18). Praktički, i to je značilo da se svaka optužena osoba koja je privedena na sudski proces smatra krivom i bila je unaprijed osuđena, što su upečatljivo potvrđivali i unaprijed tiskani obrasci presuda vijeća vojnoga suda kod Komande varaždinskog područja, u kojima je, uz ostalo, bila unaprijed otisnuta i presu- 
da "Kriv je" (v. Jurčević i Ivanda, 2006.b, 1071), s tim što nisu postojali obrasci s unaprijed otisnutom presudom "nije kriv" niti je sačuvana ijedna oslobađajuća presuda.

\section{PRESUDE VOJNIH SUDOVA}

U presudi od nepune četiri stranice Vojni sud Komande Južno Dalmatinskog Područja osudio je - 26. listopada 1944. g. u Dubrovniku 35 civilnih osoba na smrt strijeljanjem i konfiskaciju imovine "za djelo izdaje Narodno-oslobodilačke borbe naroda Jugoslavije, djelo iz člana 16 Uredbe", kako je navedeno u uvodnom dijelu presude (HDA, f. Zemaljske komisije Hrvatske za utvrđivanje zločina okupatora i njegovih pomagača [ZKRZ], k. 27, o. 2, "Broj službeno 1/44").

U presudi se "djelo izdaje" pogrešno smješta u članak 16 Uredbe (iako se stvarno nalazi u članku 14). Ovo upućuje na činjenicu s kolikom su nepažnjom pisane čak i presude u kojima je na smrt osuđeno 35 osoba te koliko je zapravo bilo nevažno što se navodi u presudi, jer je jedino važno bilo ukloniti osobe koje su nepoželjne režimu te sudskom presudom poslati javnosti jasnu poruku o karakteru nove vlasti. Osim toga, u članku 16 Uredbe samo su propisane vrste kazni i zaštitnih mjera, ali nigdje u Uredbi nije specificirano koje se kazne i zaštitne mjere vežu uz pojedina kaznena djela.

U ovoj su presudi još zanimljiviji i znakovitiji navodi $u$ kratkom dispozitivu i obrazloženju presude. U dispozitivnom se dijelu općenitim formulacijama zbirno za sve osuđene navodi kako su "svijesno i dobrovoljno stupili u aktivnu službu neprijatelja-fašističkog okupatora ... špijunirajući u korist neprijatelja", pa su na taj način "saradjivali na fizičkom uništavanju i zlostavljanju rodoljuba, pljački i uništavanju njihove imovine" i sl. Zatim se zaključuje kako su, stoga, pomagali "izdaju organizovanu i vodjenu od strane domaćih izdajnika naših naroda" (presuda, str. 2), uz ponovno pogrešno pozivanje na članak 16 Uredbe.

U obrazloženju se navodi kako su optužene osobe osuđene "kao članovi raznih vojnih organizacija", što je protivno uvodnom dijelu presude, gdje su za 31 osobu navedena civilna zanimanja, a četvorica su navodno bila "policijski agenti".

Nadalje, svim osuđenim osobama također su ukratko inkriminirane apstraktne složenice o navodnom pomaganju neprijatelju i "izdaji naroda" te se zaključilo: "Prednje činjenice sud je utvrdio na osnovu djelomičnih priznanja optuženih ... zatim iz zapljenjene neprijateljske arhive po raznim službenim biroima" te "iskazima saslušanih svjedoka da su optuženi poznati narodni neprijatelji, koji su aktivno saradjivali sa okupatorom i bili potstrekači mnogih zločina ... Na kraju, krivičnu odgovornost optuženih za pomenuta djela Sud je utvrdio i na 
DRUŠ. ISTRAŽ. ZAGREB GOD. 21 (2012) BR. $4(118)$

STR. 1007-1026

JURČEVIĆ, J.: OSNOVNE ŻNAČAJKE... osnovu općeg uvjerenja javnog mnijenja koje prevladjuje kod širokih narodnih slojeva u Dubrovniku i oklini (okolini, op. a.)" (presuda, str. 4). Pritom se nigdje u presudi ne navodi ni jedna konkretna inkriminirajuća činjenica, naziv ili citat iz arhivske građe, ime svjedoka i sl., kao ni bilo kakav podatak o ispitivanju ili drugom načinu utvrđivanja javnoga mišljenja.

U presudama koje su se na dubrovačkom području odnosile samo na jednu osobu sudski postupak i tekst presuda bili su još jednostavniji i kraći. Primjerice, sredinom studenoga 1944. presudom (na jednoj stranici) osuđen je katolički svećenik, Grković don Luka, "na kaznu smrti strijeljanjem, gubitkom građanske časti i konfiskacijom imovine", jer je navodno "za vrijeme svog službovanja u Liscu bio neprijateljski raspoložen prema NOP-a" te što je navodno "prigodom sastanka sa popom Salacanom, istom medju ostalim rekao, da je narod stoka i da mu se ne smije dati vlast $\mathrm{u}$ ruke" (HDA, ZKRZ, k. 27, o. 2, "SUD br. 1/44, od 19 XI. 1944".).

U drugoj polovici studenoga 1944. u Dubrovniku je Tomo Knego, "Hrvat, rkt. (rimokatolik, op. a.)", osuđen na "jednu godinu prisilnog rada i dvije godine gubitka gradjanskih časti te 500.000 kuna novčane kazne" jer je "1941 do oslobodjenja Dubrovnika bio četnik", a glavni optužujući konkretni navod bio je taj što se optuženi bavio "jakim švercom soli", tj. prodavao je sol u hercegovačkim selima koja su bila pod nadzorom četnika te je od njih dobivao i propusnice.

Potkraj siječnja 1945. u Dubrovniku je Miroslav Šustal "čehoslovački državljanin ... gostioničar" osuđen na "kaznu smrti strijeljanjem, gubitak gradjanskih prava i konfiskaciju imovine" jer je "hvalio Njemce kao nosioce kulture, reda i rada te što je hvalio pobjedu njemačkog oružja", a osim toga "se družio i čašćavao u svojem bifeu agente gestapoa", pa je sud na temelju ovih navoda zaključio kako je optuženi navodno "vršio špijunažu" (HDA, ZKRZ, k. 27, o. 2, "SU. Br 111/44, Dubrovnik dne 27 januara 1945", str. 1).

Okrivljeni se uzalud branio da nije špijunirao - nego je radio u svojoj djelatnosti "zbog toga kako bi što bolje pravio poslove". No sudsko vijeće imalo je svoje tipične argumente protiv optuženoga: " ... poznato je uopće po Dubrovniku da je opasan i podmukao tip koji je uvijek bio spreman na najgore, te prelazio preko svih obzira kad se radilo o tome da se što bolje zaradi" (presuda, str. 2).

U jedinoj sačuvanoj (u HDA u Zagrebu) presudi sa zadarskog područja Vojni sud III P.O.S. (Pomorska oblast sektora) osudio je, potkraj rujna 1944. Antu Kartelu na kaznu smrti vješanjem zbog djela koja su u presudi (od stranice i pol) navedena u čak 16 točaka. Optužba je navela kako je okrivljeni, sam ili s drugima, izvršio ukupno 61 ubojstvo, 16 silovanja, 83 
DRUŠ. ISTRAŽ. ZAGREB GOD. 21 (2012), BR. 4 (118)

STR. 1007-1026

JURČEVIĆ, J.: OSNOVNE ZNAČAJKE... paleža kuća i jedne crkve, 7 masakriranja vađenjem očiju, a s još jednom osobom pokušao je "na ražnju živa ispeći nekog (n. a.) rodoljuba koji im je gol pobjegao". Zanimljivo je kako se, od svih zastrašujućih djela navedenih u presudi, jedino za dva silovanja navode imena žrtava - od kojih je jedna bila "žena Kočina", a za sva ostala djela navode se tek mjesta bez vremenske naznake kada su počinjena, tko su žrtve ili oštećenici te bez drugih konkretnijih naznaka (HDA, ZKRZ, k. 27, o. 2, "S. Broj 39/44, 25. Sept. 1944").

U desetak redaka obrazloženja uopće se konkretno ne dokazuje ni jedna točka optužbe, nego se navode opće formulacije kako je Kartela Ante "stupio u bandu ... a banda je klala bez milosrdja, oni nisu poznavali nikakova zakona ni vjere ni djevojačke časti. Njima je bilo svejedno. Ubijali su mirne gradjane, silovali nemoćne žene, kopali oči sitnoj djeci. Palili su crkve i domove, otimali imovinu. Kartela je bio jedan od tih izroda ... Za njegova djela nema kazne na ovomu svijetu. Ovakovo zlo kao što je Kartela Ante trebalo je čim prije ukloniti sa divnog svijeta iz sredine našeg junačkog naroda".

Na kraju se zaključilo kako treba "ovu presudu pročitati pred strojem svim borcima sa potrebnom poukom" te da je presuda dostavljena "svim podredjenim jedinicama sektora" (presuda, str. 1-2).

Sačuvane presude s ličkoga područja uglavnom su skupne, pa su dispozitivi i obrazloženja naglašeno kratki i deklarativni, a u slučajevima kad su se optuženi branili kako nisu počinili djela koja su im stavljana na teret, sud je to redovito bez obrazloženja odbacivao uz često navođenje najjednostavnije formulacije kako je obrana "neumjesna" (npr. HDA, ZKRZ, k. 27, o. 3, "Sud broj 339/45, 13 jula 1945").

U presudama s ličkoga područja nalazi se prosječno znatno veći broj osuđenih žena nego u presudama vojnih sudova s ostalih dijelova Hrvatske (Osobna svjedočanstva više desetaka osuđenih žena te poimenični popis i drugi osnovni podaci o 3016 žena osuđenih u montiranim političkim sudskim procesima u Hrvatskoj u vrijeme komunizma - uključujući i žene osuđene od vojnih sudova u neposrednom poraću - objavljeni su u knjizi: Pereković, 2004.).

Poratne presude ženama izrečene od vijeća vojnoga suda kod ličke Komande područja veoma su kratke i uglavnom sa znatno blažim kaznama nego presude muškarcima. Primjerice, na manje od stranicu i pol osuđeno je sedam žena na kaznu prisilnoga rada od šest do dva mjeseca, pod zajedničkom poopćenom inkriminacijom "što su išle uzeti žito 1941 od prognanog naroda u Divoselu" i "što su aktivno simpatizirale ustaše ... te širile lažnu neprijateljsku propagandu" (HDA, ZKRZ, k. 27, o. 3. "S. Br. 87/45 od 5 juna 1945"). 
DRUŠ. ISTRAŽ. ZAGREB GOD. 21 (2012) BR. $4(118)$

STR. 1007-1026

JURČEVIĆ, J.:

OSNOVNE ŻNAČAJKE...
Isto tako, Vijeće kod ličke Komande područja, u skupnoj presudi (na dvije stranice) osudilo je osam žena, pod pojedinačnim inkriminacijama, na kazne prisilnog rada između $16 \mathrm{i}$ 3 mjeseca. A inkriminacije su bile sljedeće: " ... vodila ljubav s ustaškim žandarom ... te preko njega ... vršila špijunažu u korist neprijatelja"; "... odlazila u Gospić oko 10 puta, a u Karlobag oko 15 puta u cilju šverca, te na taj način vršila špijunažu u korist ustaša"; "Što se je sastajala sa ustaškim tabornikom ... te zajedno sa svojom kćerkom vršila špijunažu u korist neprijatelja"; "Što je preko svoga brata koji je bio ustaški vodnik, vršila špijunažu u korist ustaša"; "Što je ... odlazila u Karlobag 5 puta po šverc, te istom prilikom sastajala se sa ... ustaškim vodnikom kojem je donosila razne vijesti o Partizanima"; "što je išla zajedno s ustašom ... u Karlobag u cilju šverca i vršila špijunažu u korist ustaša" itd. (HDA, ZKRZ, $k$. 27, o. 3, "S. Broj 87/45 dne 16-V-1945").

Zagrebačka vojna oblast obuhvaćala je gusto naseljenu i veliku površinu cijeloga sjeverozapadnog dijela Hrvatske. S tog je prostora (u odnosu na druge vojne oblasti u Hrvatskoj) sačuvan ukupno najveći broj presuda. No i ovdje je sačuvan tek manji dio od ukupnoga broja presuda izrečenih na području Zagrebačke vojne oblasti (v. Jurčević i Ivanda, 2006.b, str. 1068-1074).

Posebnu zanimljivost među sačuvanim presudama s područja grada Zagreba čini približno 1500 sačuvanih fragmenata ("rezanaca") iz presuda. Radi se o pažljivo izrezanim dispozitivima presuda, koji su opsega nekoliko redaka i u kojima su navedeni osnovni identifikacijski podaci o osuđenim osobama, visini i vrstama kazne te kratka formulacija o vrsti inkriminacije.

U sačuvanim presudama Vojnog suda oblasti Zagrebačke J. A. (Jugoslavenske armije, op. a.) - Vijeće kod Komande grada Čakovca najveći broj inkriminacija odnosio se na razne oblike navodne neprijateljske suradnje s mađarskim okupacijskim vlastima, pa je stoga zanimljivo navesti neke tipične konkretne primjere kako bi se vidjeli oblici te navodne neprijateljske suradnje i visine izrečenih kazni.

Na početku lipnja 1945. osuđen je Mekovec Antun "na kaznu robije u trajanju od deset (10) godina i na gubitak gradjanske časti za uvijek" jer je "stupio u 'Njilas' partiju ... pa je time počinio krivično djelo pripadništva protunarodnoj organizaciji", zatim, jer je "prisustvovao njenim (partijskim, op. a.) sastancima ... pa je time počinio djelo širenja neprijateljske propagande" (HDA, ZKRZ, k. 27, o. 1, "SUD. Broj: 3/1945, Dana 5. lipnja 1945", str. 1).

Okrivljeni se branio kako je ušao u "Njilas" partiju "da bi dobio veću platu i namještenje, a kada je vidio da to neće dobiti nije ništa više radio za tu partiju", no sud je "obranu okrivlje- 
DRUŠ. ISTRAŽ. ZAGREB GOD. 21 (2012), BR. 4 (118),

STR. 1007-1026

JURČEVIĆ, J.: OSNOVNE ZNAČAJKE... nog odbacio kao neumjesnu", jer program "Njilas" partije "nije bio na socijalnoj već na političkoj osnovi, te mu je bio jasan cilj partije: odnarodjivanje našeg naroda" (presuda, str. 2).

Na početku lipnja 1945. osuđen je Ivan Škvor "na kaznu smrti strijeljanjem, gubitkom gradjanskih časti za uvijek i konfiskacijom njegove imovine u korist Narodno Oslobodilačkog Fonda" (HDA, ZKRZ, k. 27, o. 1, "Sud. br. 30/1945, Dana 1. lipnja 1945", str. 2) jer je "za vrijeme bivše Jugoslavije bio član vijeća 20-torice", koje je imalo cilj da se Međimurje "pripoji Mađarskoj ... pa je time počinio krivično djelo pokretača i organizatora izdajstva države"; zatim, što je u vrijeme rata "ušao u gradski odbor te sa ostalim članovima odbora odredjivao ljude za vojnički rad u Mađarskoj ... pa je time počinio krivično djelo masovnog odvodjenja na prisilni rad"; što je "1941. prilikom dolaska Madjara u Medjimurje, medju prvima izvjesio madjarsku zastavu ... pa je time počinio krivično djelo služenja neprijatelju kao pomagač"; što je "prisustvovao konfiskaciji i prodavanju židovske imovine kupivši (n. a.) kod toga 1. klavir, 2. blagajne, 1. dječju klupu te 1 . krletku sa 15 zečeva, pa je time počinio krivično djelo pljačke narodne imovine" (presuda, str. 1-2).

Okrivljeni se branio "da vijeću 20-torice nije pripadao za vrijeme Jugoslavije", zastavu je "dao sašiti prije dolaska Madjarskih trupa kad je vidio, da to i drugi čine", a stvari je kupio "na licitaciji koju su drugi održavali" (presuda, str. 3). Međutim, "obranu okrivljenog sud je odbacio kao neumjesnu", a potom je zaključio "da je okrivljeni kriv za sva djela" te da je "okrivljeni po svom karakteru pokvaren izrod koji je uvijek mislio samo na sebe; lice koje je uvijek bilo pristaša svakog odozgo diktiranog režima i priviknuto na koristi od služenja režimu" (presuda, str. 3).

Istoga dana osuđen je i Josip Jalušić "na kaznu smrti strijeljanjem, gubitkom gradjanskih časti za uvijek te na konfiskaciju njegove imovine u korist N.O.F-onda" (HDA, ZKRZ, k. 27, o. 1, "Sud. br. 4/1945, Dana 1. lipnja 1945", str. 2) jer je "stupio u 'Magyar Elet' partiju ... primio od madjarskih vlasti dužnost odbornika za svoje selo ... odlazio sa madjarskim žandarima po selu u svrhu rekvizicije ... sudjelovao ... u raciji na vojne bjegunce u svom selu" (presuda, str. 1).

Ni u ovom slučaju "sud nije uvažio obranu okrivljenog a njegova krivnja dokazana je priznanjem", pa je sud "stekao uvjerenje da je okrivljeni narodni izrod i otvoreni narodni neprijatelj koji za obećanu mu korist ... prodaje sebe i svoje ime, tuži druge i pomaže najvećem neprijatelju našega naroda" (presuda, str. 3).

Na presudi od jedne stranice izrečenoj na početku srpnja 1941. Vojni sud oblasti "Zagrebačke" J. A. - Vijeće kod komande grada Varaždina osudio je Kristek Maksa (starog 64 
DRUŠ. ISTRAŽ. ZAGREB GOD. 21 (2012) BR. $4(118)$

STR. 1007-1026

JURČEVIĆ, J.:

OSNOVNE ZNAČAJKE... godine) "na kaznu smrti streljanjem, trajan gubitak gradj. časti i konfiskaciju njegove imovine", jer je "u svojoj brijačnici denuncirao nekom 'Gestapovcu' drugove ... koji su ... bili uhapšeni i na varaždinskoj policiji ispremlaćeni" te što se "upisao u švapsku organizaciju 'Volks-grupu', kao takav pohadjao sastanke" (HDA, ZKRZ, k. 29, o. 2, "Sud. br. 82/45, Dne 1. srpnja 1945").

U obrazloženju je okrivljeni opisan kao "bijedni, prljavi fašistički tip koji pod stare dane ulazi nepotrebno u fašističku organizaciju", a potom je zaključeno: " ... isti taj prljavi starac kako je gmizio i ulagivao se švabskim koljačima isto tako daje bjednu sliku i pred viječem, gdje govori plačući o svojoj nekrivnji" te "svojim utiskom uvjerio je viječe da je počinio odanošču za švabe sva gore navedena djela pa je zaslužio kaznu".

Sačuvane su još dvije presude koje je isti sastav sudskoga vijeća donio istoga dana i koje su na veoma sličan način koncipirane.

Jednom je presudom osuđen Josip Gregov "na kaznu smrti streljanjem trajan gubitak gradj. časti konfiskaciju njegove imovine" jer je "stupio u redarstvo u Zgb. i kao izvidnik ... vršio kroz 15. dana stražu u Tuškancu ne propuštajući ljude bez propusnice, a zatim je primljen u kancelarijsku službu gdje je vršio pregled sa racije uhapšenih osoba" (HDA, ZKRZ, k. 29, o. 2, "Sud. br. 90/45, dne 1. srpnja 1945", str. 1).

Okrivljenik se branio kako je "stupio u redarstvo u borbi za kruh" te da je "pregledavajući spisak sumnjivih gledao samo na kriminalce a ne na političke sumnjivce". No sud je odlučio kako je njegova obrana "neumjesna, jer je poznato da su sve racije za N.D.H. bile političkog karaktera". Na kraju obrazloženja presude zaključeno je: "Ako se ima u vidu da je okr. sačinjavao prljavi i krvavi agentski ološ od kojeg je ne samo strepio nego od kojeg je uglavnom stradao naš narod, onda je jasno da je vijeće donijelo gornju presudu koja jedino odgovara krivnji okrivljenog" (presuda, str. 2).

Drugom presudom osuđen je Milan Knobloh "na kaznu smrti streljanjem, trajan gubitak gradj. časti i konfiskaciju njegove imovine" jer je "u svojstvu činovnika u uredu za manipulaciju opljačkanih predmeta ... i sam opljačkao niz kuhinjskog posudja i raznih drugih predmeta" te što je kasnije obavljao "dužnost cenzuoa na pošti u Varaždinu" (HDA, ZKRZ, k. 29, o. 2, "Sud. br. 141/45, Dne 1. Srpnja 1945", str. 1). Prema navodu u presudi, okrivljenik je priznao djela, a vijeće je u obrazloženju dodatno navelo: "Ako se uzme u obzir da se družio samo s ljudima ust. duha ... da mu je sin ... služio u poznatom krvavom IV. Gorskom zdrugu ... vidi se njegova povezanost za ust. režim pljačke i terora, pa ga je zbog svega toga vijeće presudilo najstrože" (presuda, str. 2). 
DRUŠ. ISTRAŽ. ZAGREB GOD. 21 (2012), BR. 4 (118), STR. 1007-1026

JURČEVIĆ, J.: OSNOVNE ŻNAČAJKE...
Na početku srpnja 1945. osuđen je Valent Abramović ("koji u J. A. nema nikoga") "na kaznu prisilnog rada u trajanju od 5 godina i na gubitak gradjanskih časti kroz 5 godina" jer je "kao bivši zaštitar ... išao da pregleda municiju u Biškupec" (HDA, ZKRZ, k. 29, o. 2, "Sud. br. 141/45, Dne 1. Srpnja 1945", str. 1), zatim što je "kao činovnik Hidro-tehničkog odjela radio na geografskim sekcijama sve do sloma NDH" i što je "sudjelovao na dočeku vojskovođe Kvaternika u Varaždinu" (presuda, str. 2). Okrivljenik je navodno priznao djela, pa je "sud na temelju priznanja našao da je kriv, a inače stekao uvjerenje da je bio pobornik ustaštva i štititelj njihove propagande" (presuda, str. 2).

Posebno je znakovita presuda ("odluka") kojom je - sredinom lipnja - vijeće vojnoga suda "kod Varaždinske komande područja", u odsutnosti okrivljenika, odlučilo da se "I. okr. Pažur Mirko i II. okr. Pažur Gjura proglašuju narodnim neprijateljima i konfiscira cjelokupna njihova imovina u korist N.O. Fonda" (HDA, ZKRZ, k. 29, o. 2, "Sud. br. 263/45, Dne 11. lipanj 1945", str. 1). Pažur Mirko osuđen je zato što je "razoružavao jug. (starojugoslavensku, op. a.) vojsku ... nagovarao na zločine i paljenje sela", a njegova supruga Pažur Đura što je "provocirala i širila ustaške ideje ... i davala inicijative za zločine" (presuda, str. 1).

Međutim, u obrazloženju presude mogu se iščitati pravi razlozi procesuiranja supružnika Pažur. Naime, oni su "okrivljeni kao roditelji zloglasnog ustaškog satnika i logornika Rikarda Pažura", jer sud tvrdi kako je "jasno (n. a.) da su ga okrivljeni svojim savjetom i moralno potpomagali", a na temelju iste logike sud je nastavio zaključivanje: "Okrivljeni svojim potstrekavanjem dokazuju čvrstu činjenicu (n. a.) da su nepopravljivi i okorjeli fašisti koji su svojim indirektnim a-li vjerojatno radom (n. a.) učinili velike nepravde našem teško prepaćenom narodu" (presuda, str. 2).

Sud je istoga dana i pod istim sudskim brojem donio i zasebnu presudu ("odluku") kojom se i Pažur Rikard (sin Mirka i Đure) "u odsutnosti ... proglašuje ... narodnim neprijateljem i konfiscira cjelokupna njegova imovina u korist Narodno Oslobodilačkog Fonda" (HDA, ZKRZ, k. 29, o. 2, "Sud. br. 263/45, Dne 14 lipanj 1945").

Prema cjelovito sačuvanoj presudi, sredinom srpnja 1945. Vojni sud Komande grada Zagreba osudio je Vladimira Ruždjaka "na kaznu prisilnog rada bez lišenja slobode kroz (5) pet mjeseci i na gubitak prava na državnu službu", jer je "od 1942 godine radio na glavnom ravnateljstvu za promičbu i to prije na urudžbenom zapisniku a kasnije kao blagajnik. Od 1. IX 1943 bio je član zbora radio stanice i kao takav sudjelovao u koncertima u kojima se ustaškim pjesmama širila propaganda" (HDA, ZKRZ, k. 29, o. 4, koverta V, "Sud. br. 827, dne, 18. VII. 
DRUŠ. ISTRAŽ. ZAGREB GOD. 21 (2012) BR. $4(118)$

STR. 1007-1026

JURČEVIĆ, J. OSNOVNE ZNAČAJKE..
1945"). Zanimljivo je da je V. Ruždjak kasnije postao svjetski slavan operni pjevač, no u njegovu životopisu zaobilažene su sve činjenice iz ratnoga razdoblja (v. Barbieri, 2011. i Madžar, 2009.).

Sredinom kolovoza 1945. osuđen je Stjepan Žiger "na kaznu smrti streljanjem, trajan gubitak svih političkih i gradjanskih prava, te na konfiskaciju njegove imovine", zbog toga što je "1942. vršio špijunsku službu u logoru Stara Gradiška, kao zatvorenik bio na povjerljivim mjestima $u$ kancelariji logora političkom otsjeku, nadziratelj radova na bedemu, trgovinom izrabljivao bijedno stanje logoraša, družio se sa ustaškim oficirima i imao povlastice u logoru kao i svaki ustaša" (HDA, ZKRZ, k. 29, o. 4, koverta VIII, "Sud. br. 1503/45, Dne 16. VIII. 1945").

U prvoj polovici kolovoza 1945. osuđen je Miroslav Aroh "na kaznu smrti streljanjem, trajan gubitak svih političkih i gradjanskih prava, te na konfiskaciju njegove imovine u korist države" jer je "1938. g. prilikom ulaska Nijemaca u Austriju dao oduška svojim njemačkim osjećajima na taj način, što je širom otvorio prozore kako bi se na njegov radio čuo govor Hitlera i na ulicu, a od radosti da efekt bude veći lupao je nogama po podu", zatim, što je "1941. g. postao član fašističke organizacije Kulturbund" (HDA, ZKRZ, k. 29, o. 4, koverta IX, "Sud. br. 1615, dne 7-VII-1945").

Dan kasnije osuđen je Josip Heršak "na kaznu smrti streljanjem, trajan gubitak gradjanskih i političkih prava i konfiskaciju imovine" zbog toga što je "kao zatočenik u logoru Jasenovac u 1942 i u polovini 1943 radio kao zidar zlostavljao druge zatočenike i tako ćuškao i tukao čekićem po nogama one koji su mu pomagali pri poslu, te sa još nekolicinom zidara učestvovao u izgradnji peći za spaljivanje ljudi", zatim "što je za svog boravka u logoru poznatom ustaškom koljaču Zrinjušić Anti prokazivao mnoge zatočenike da neće da rade ili da kane pobjeći, te su ovi prilikom 'nastupa' bili odvajani i mnogi medju njima likvidirani" (HDA, ZKRZ, k. 29, o. 4, koverta IX, "Sud. br. 1627, 8. VIII. 45").

Sredinom kolovoza 1945. osuđen je Ante Paša "na kaznu smrti streljanjem, trajan gubitak gradjanskih i političkih prava i konfiskaciju imovine", jer je postao član redakcije novoosnovanoga ustaškog lista 'Danas' ... a nakon ukidanja lista 1942 stupio najprije u službu propagandnog ureda ... a zatim primio se službe u glavarstvu gradjanske uprave" (HDA, ZKRZ, k. 29, o. 4, koverta IX, "Sudb. Br. 1727, 13. augusta 1945").

Liječnik Mile dr. Budak osuđen je "na 7 godina lišenja slobode sa prinudnim radom, 10 godina gubitka svih političkih $\mathrm{i}$ gradjanskih prava i konfiskaciju imovine" zbog toga što je "kao lični lječnik 'Poglavnika' (A. Pavelić, op. a.) od nastanka ustaške vlasti do oslobodjenja naše zemlje, lječio 'Poglavnika', za 
DRUŠ. ISTRAŽ. ZAGREB GOD. 21 (2012), BR. 4 (118),

STR. 1007-1026

JURČEVIĆ, J.: OSNOVNE ZNAČAJKE... koje vreme ga je pratio na svim njegovim putovanjima u zemlji i inozemstvu" te što je "primio od Pavelićevog ministra Nikšića kuću u Gregorjančevoj 7 koja je pripadala Ladanji, a koji je prognat od ustaša" (HDA, ZKRZ, k. 29, o. 4, koverta IX, sud. br. "1784/45"). Dodatno je objašnjeno i zamjereno okrivljeniku što je na taj način "svoje lječničko znanje stavio u službu ustaškog pokreta, te se u toj službi pokazao naročito aktivan i vrijedan."

U prvoj polovici lipnja 1945. Vojni sud Vojne oblasti za Slavoniju, Vijeće kod Novogradiške komande područja osudilo je Iliju Kovačevića "na kaznu smrti streljanjem, trajan gubitak gradjanskih časnih prava i konfiskaciju njegove imovine" zbog toga što je "odmah po osnutku NDH dobrovoljno stupio u ustašku organizaciju", a sredinom lipnja 1942. je "stupio u ustašku pripremnu bojnu" (HDA, ZKRZ, k. 28, o. 1, "Sud. Br. 345, 1945, Dana 10. VI. 1945"). U obrazloženju je navedeno kako okrivljeni snosi "punu odgovornost za sva nedjela koja su učinile ustaše u Požeškom kotaru" - "mada on sam nije ubijao, pljačkao i palio."

Isti sastav sudskoga vijeća izrekao je nakon nekoliko dana - pri sličnoj inkriminaciji - radikalno blažu kaznu, tj. osudio je Matu Rafajca "na kaznu prisilnog rada u trajanju od četiri (4) mjeseca i četiri (4) godine gubitka gradjanskih prava" (HDA, ZKRZ, k. 28, o. 1, "Sud. Br. 326, 1945, Dana 16 VI 1945"). U dispozitivu je navedeno kako je okrivljenik "od 12. I. 1945 pa do raspada NDH bio pripadnik XIV. ustaškog stajaćeg zdruga" te "dakle bio aktivni ustaša". Ni u obrazloženju nema naznake zbog čega je sudsko vijeće u ovom slučaju postupilo bitno drugačije nego u prethodno navedenoj presudi, pa čak i neuobičajeno blago u odnosu na presude drugih sudova u $\mathrm{Hr}$ vatskoj kad se radilo o sličnoj inkriminaciji.

Potkraj travnja 1945. godine - Vojni sud VI Korpusne vojne oblasti - Vijeće kod komande osječkog područja osudilo je Ivana Kuzmanovića "na kaznu smrti streljanjem, trajan gubitak gradjanskih prava i vojničke časti te konfiskaciju njegove imovine u korist NO Fonda" jer je "1942 godine dobrovoljno pristupio u ustašku organizaciju ... dobrovoljno stupio u ustašku bojnu ... kao ratnik iz 1914-1918 odlikovan od bivše Austrije išao u Zagreb na poklonstvenu deputaciju Anti Paveliću i o tome kasnije širio protivnarodnu ustašku propagandu" (HDA, ZKRZ, k. 28, o. 1, "SUD. br. 17/45", u uvodu presude naveden je datum "9. IV. 1945").

Vojni sudovi procesuirali su i pripadnike HSS-a za djela iz vremena Kraljevine Jugoslavije, a koja su u to vrijeme bila redovita djelatnost te stranke. Tako je sredinom svibnja 1945. godine Vijeće kod komande osječkog područja osudilo Šimu Kuruca "na kaznu smrti streljanjem, konfiskaciju njegove imovine $\mathrm{u}$ korist Narodnooslobodilačkog Fonda i na trajan gubi- 
DRUŠ. ISTRAŽ. ZAGREB GOD. 21 (2012) BR. $4(118)$

STR. 1007-1026

JURČEVIĆ, J.:

OSNOVNE ZNAČAJKE... tak gradjanskih prava i vojničke časti" jer je "u jesen 1939 godine stupio u 'Seljačku zaštitu', koja organizacija je već za vrijeme Jugoslavije pokazala svoj protivnarodni rad", zatim što je "1942. god. dobrovoljno stupio u protivnarodnu ustašku terorističku organizaciju", a "1943 g. stupio u 4 sat I ustaškog zdruga željezničke bojne ... a početkom mjeseca aprila 1944 g. stupio u zloglasnu Stirovu XVI ustašku bojnu" (HDA, ZKRZ, k. 28, o. 1, "Sud. br. 58/1945", u uvodu presude naveden je datum "10 maja 1945").

Međutim, ovu kaznu - na početku lipnja 1945. godine Vojni sud II Jugoslavenske Armije nije odobrio, nego je Š. Kuruca kaznio "na pet godina prisilnog rada i tri godine gubitka gradjanske časti" uz obrazloženje: "Za Kuruc Simu kazna je donesena preoštro, ako se uzme u obzir, da osudjeni nije dobrovoljno stupio $u$ neprijateljske oružane formacije i da nije sudjelovao u akcijama" (HDA, ZKRZ, k. 28, o. 1, "II. Sud. Br. 959-974/45, 5 juna 1945").

Slično je bilo i s jednim drugim osuđenikom. Isti sastav sudskoga vijeća iz prethodne presude osudio je i Florijana Koškija "na kaznu smrti streljanjem, trajan gubitak gradjanskih prava i vojničke časti i na konfiskaciju njegove imovine u korist NO Fonda" zbog toga što je "po preokretu stupio u narodnu zaštitu kao prikriveni ustaša ... što je kao pripadnik narodne zaštite razoružavao bivšu jugoslavensku vojsku" te što se "dobrovoljno upisao u terorističku protivnarodnu ustašku organizaciju" i "bio na straži u Humljanima u području Vojlovice i u Zagrebu, čuvajući razne objekte od napadaja NOV" (HDA, ZKRZ, k. 28, o. 1, "SUD. br. 64/45").

Ni ovu kaznu nije odobrio Vojni sud II Jugoslavenske Armije, nego je F. Koškija kaznio s "deset godina prisilnog rada i pet godina gubitka gradjanske časti" (HDA, ZKRZ, k. 28, o. 1, "II. Sud. br. 959-974/45, 5 juna 1945").

Potkraj lipnja 1945. osuđen je Stjepan Molnar "na kaznu lišenja slobode uz prinudni rad $u$ trajanju od petnaest (15) godina i na gubitak gradjanskih prava u trajanju od deset (10) godina" zbog toga što je "u Vinkovcima učestvovao u razoružavanju biv. jugosl. vojske", što je "13. IV. 1941. g. u Vinkovcima kada je Seljačka zaštita vodila Svetislava Nikolića kao uhapšenika udario u pleća puškom Svetislava Nikolića", što je "u preokretu 1941. g. kada je sa ostalom zaštitom prepraćivao hapšenike, držao naperenu pušku prema Panajotović Mihajlu, dok su Panajotovića pretresali jedan civil i jedan policajac" te što je "bio član njemačkog kulturnog društva 'Kulturbund"' i "pripadnik ustaške organizacije" (HDA, ZKRZ, 1. 28, o. 1, "Sud br. 27/45, Osijek, 25. VI. 1945", str. 1).

U obrazloženju presude navedeno je kako je sud osuđenom "uzeo kao otežicu neprijateljski stav protiv naroda i NOB-e te 
DRUŠ. ISTRAŽ. ZAGREB GOD. 21 (2012), BR. 4 (118),

STR. 1007-1026

JURČEVIĆ, J.: OSNOVNE ZNNAČAJKE.

\section{ZAKLJUČAK}

njenih tekovina, što je okrivljeni okorjeli fašista, zao karakter i opasan po društvo" (presuda, str. 2).

Potkraj srpnja 1945. Vijeće kod Komande osječkog područja osudilo je Ružicu Pffaf (rođenu 1925. godine) "na kaznu lišenja slobode s prinudnim radom u trajanju od dva mjeseca (2) i dvije godine gubitka političkih prava" jer je "od preokreta 1941. g. do oslobodjenja 1945. g. u neustanovljene dane oko dva puta (n. a.) na razglasnoj stanici u Vinkovcima pjevala pjesme, medju njima i takve ustaškog sadržaja", te je na taj način "počinila djelo suradnje s neprijateljem" (HDA, ZKRZ, k. 28, o. 1, "Sud. broj: 1011/45, Osijek, 30. VII. 1945").

Iz navoda u obrazloženju presude saznaje se kako je osuđena priznala "da je u dva maha pjevala na vinkovačkoj razglasnoj stanici za vrijeme rata, ali da su to bile sevdalinke" te da je njezin "otac bio u tajnoj njemačkoj policiji i kao takav poginuo za vrijeme rata." Međutim, sud navodi kako prema izvješću OZN-e proizlazi "da je okrivljena bila u dobrim odnosima sa neprijateljskim policajcima, a naročito zloglasnim kotarskim pretstojnikom Tolj Ivanom" te "sud smatra, da je okrivljeničinim priznanjem u vezi sa navedenim izvještajem 293 dokazano, da je okrivljena počinila voj. kr. djelo opisano u dispozitivu."

Pritom je ostalo nerazjašnjeno kako je pjevanje pjesama, koje je jedino opisano u dispozitivu, moglo biti dokazano dobrim odnosima s "neprijateljskim policajcima". Osim toga, sud uopće nije razmatrao pitanje je li okrivljena bila malodobna u vrijeme kad je pjevala, tj. kad je počinila vojno krivično djelo.

Zajedničko obilježje gotovo svim sačuvanim presudama vojnih sudova sa svih područja Hrvatske jest to što dispozitivni dijelovi i obrazloženja presuda uopće ne sadrže konkretna počinjena djela, nego opće formulacije o pripadnosti nekoj suparničkoj vojsci, stranci, pokretu, kulturnom udruženju i sl., na temelju čega su građene proizvoljne ideologizirane konstrukcije o samorazumljivoj krivnji koja se time smatrala dokazanom.

Budući da se u rijetkim presudama radilo o navođenju konkretnih počinjenih djela, ali se ni u njima ne prepoznaju tragovi objektivnoga dokazivanja i neovisnih (objektivnih) prosudbi sudskih vijeća, onda se može smatrati da - načelno - $\mathfrak{u}$ procesima pred vojnim sudovima krivnja osuđenih osoba nije bila događajno i logički utemeljena. O ovome svjedoči i podatak da nije sačuvana ni jedna oslobađajuća presuda jugoslavenskih komunističkih vojnih sudova iz 1944. i 1945. godine, što potvrđuje da su osobe koje su bile izvedene pred sud zapravo bile unaprijed osuđene, bez obzira na stvarnu krivnju. 
DRUŠ. ISTRAŽ. ZAGREB GOD. 21 (2012) BR. $4(118)$

STR. 1007-1026

JURČEVIĆ, J. OSNOVNE ZNAČAJKE...
Ako se u obrazloženju presude ukratko navodio pokušaj okrivljenika da otkloni navode optužbe, onda se on u gotovo svim presudama odbacivao pod raznim izričajima, koji su se kretali od neobrazloženoga konstatiranja navodne neosnovanosti obrane do čestih neobrazloženih ponižavajućih i uvredljivih zaključaka o optuženiku.

Prema svim sačuvanim presudama očito je da su sudske rasprave dovršavane vrlo brzo, bez izvođenja i provjere dokaza o krivnji. Kazne su uglavnom bile drakonske i revolucionarno nemilosrdne, a nije uopće ni bila predviđena mogućnost podnošenja žalbe. U presudama su redovito izricane i zaštitne mjere oduzimanja izbornoga i drugih građanskih i časnih prava. Svrha toga bila je u stvaranju općega društvenog ozračja straha te $u$ psihološkom, socijalnom i pravnom diskriminiranju osuđenih osoba, njihovih svjetonazora, stavova i istomišljenika, kako bi ih se na taj način uklonilo iz izravnoga sudjelovanja te iz bilo kakve mogućnosti utjecanja na politički i cjelokupni javni život, kojim je upravljao totalitarni komunistički poredak. U svim sačuvanim presudama optuženim osobama nije omogućeno pravo na branitelja, a ostajali su i bez mogućnosti ikakve činjenične i razumske obrane.

Posebno značenje imalo je i redovito izricanje zaštitne mjere o oduzimanju (konfiskaciji) imovine osuđenim osobama, jer je to bio jedan od oblika kojim je režim sustavno otimao privatno vlasništvo, koje je komunistička doktrina smatrala jednom od najvećih negativnosti u načelnom i stvarnom smislu.

Prema tome, i analiza konkretnih presuda jugoslavenskih komunističkih vojnih sudova upečatljivo pokazuje da su sudska vijeća pitanje krivnje procesuiranih osoba procjenjivala isključivo prema ideološkim kriterijima koje je nametnula KPJ radi ostvarivanja svojih revolucionarnih ciljeva. Uostalom, takav pristup bio je jasno prepoznatljiv i u pravnim normama o nadležnosti vojnih sudova. U prilog ovome zaključku govori i činjenica da su se sudski procesi veoma često odvijali uz probranu masovnu publiku i u ozračju organizirane gladijatorske arene (v. Jurčević i Ivanda, 2006.b).

Pri razmatranju pitanja kojoj su vrsti sudova u širem smislu pripadali jugoslavenski komunistički vojni sudovi, može se i na temelju analize konkretnih presuda i njihovih zbirnih značajki pouzdano zaključiti da se radilo o sudovima koji su povijesno označavani nazivom revolucionarni (izvanredni ili prijeki) sudovi, čije je glavno obilježje bilo u tome što su drastično odstupali od pravnih standarda civiliziranoga svijeta.

Duboku komunističku revolucionarnu osmišljenost i svrhu djelovanja vojnih (i drugih komunističkih) sudova jasno su sredinom 1945. naglašavali i predstavnici najviših jugoslavenskih partijskih i državnih vlasti, koji su svoje vojne i druge sudove označavali pojmom "revolucionarnih sudova", opisu- 
DRUŠ. ISTRAŽ. ZAGREB GOD. 21 (2012), BR. 4 (118)

STR. 1007-1026

JURČEVIĆ, J.: OSNOVNE ZNAČAJKE. jući ih kao "forme za energično i brzo čišćenje neprijatelja iz naših redova. Nama se dao jedan kratki period za trajanje tih revolucionarnih sudova ... da bi u najkraće vrijeme očistili zemlju od neprijateljskih elemenata i zahvatili stvar u svoje ruke" (HDA, f. OZN-a, k. 3, o. 1, "I. Savjetovanje načelnika i rukovodstva OZN-e za Hrvatsku 1945. god.", iz izlaganja izaslanika CK KPH Duška Brkića, str. 3).

Hrvatski državni arhiv (HDA): fond Zemaljske komisije Hrvatske za utvrđivanje zločina okupatora i njegovih pomagača (fond ZKRZ).

Hrvatski državni arhiv (HDA): fond Odjeljenja zaštite naroda (fond OZN-a).

Službeni list. Beograd.

Arendt, H. (1996). Totalitarizam. Zagreb: Politička kultura.

Barbieri, M. (2011). Velik, jedinstven, neponovljiv - portret Vladimira Ruždjaka. Posjećeno na: http://www.klasika.hr/index.php?p=article\& id $=1092$

Bilandžić, D. (1985). Historija SFRJ. Zagreb: Školska knjiga.

Blažević, J. (1976). Tražio sam crvenu nit. Zagreb: "Zagreb".

Courtois, S., Werh, N., Panne, J-L., Poczkowski, A., Bartošek, K. i Margolin J-L. (1999). Crna knjiga komunizma - zločini, teror, represija. Zagreb: Politička kultura i Golden marketing.

Geršković, L. (1948). Dokumenti o razvoju narodne vlasti. Beograd.

Hrnčević, J. (1984). Svjedočanstva. Zagreb: Globus.

Jurčević, J. (2005). Bleiburg - jugoslavenski poratni zločini nad Hrvatima. Zagreb: Dokumentacijsko informacijsko središte, Udruga ratnih veterana Hrvatski domobran i Hrvatsko društvo političkih zatvorenika. Jurčević, J. i Ivanda, K. (2006a). Ustrojavanje sustava jugoslavenskih komunističkih vojnih sudova tijekom Drugog svjetskog rata i poraća. Društvena istraživanja, 15(4-5), 891-915.

Jurčević, J. i Ivanda, K. (2006b). Djelovanje jugoslavenskih komunističkih vojnih sudova u Hrvatskoj potkraj Drugog svjetskog rata i u poraću. Društvena istraživanja, 15(6), 1063-1086.

Lenjin, V. I. (1973). Dječja bolest ljevičarstva u komunizmu. Zagreb: Naprijed. Madžar, Z. (2009). Jedan je bio Vladimir Ruždjak. Posjećeno na: http:// www.matica.hr/Vijenac/vijenac411.nsf/AllWebDocs

Marx, K. i Engels, F. (1973). Manifest komunističke partije. Zagreb: Naprijed. Mujadžević, D. (2011). Bakarić - politička biografija. Zagreb: Plejada i Hrvatski institut za povijest - Podružnica Slavonski Brod.

Pereković, K. (2004). Naše robijanje - hrvatske žene u komunističkim zatvorima. Rijeka-Zagreb: RINAZ - Riječki nakladni zavod.

Petranović, B. (1988). Istorija Jugoslavije 1918-1988. Beograd: Nolit. 
DRUŠ. ISTRAŽ. ZAGREB GOD. 21 (2012)

BR. $4(118)$

STR. 1007-1026

JURČEVIĆ, J.

OSNOVNE ZNAČAJKE..
Puhovski, Ž. (1990). Socijalisticka konstrukcija zbilje. Zagreb: Školska knjiga. Sagrak, D. (2006). Mile Budak o sebi, i drugi o njemu. Zagreb: Naklada Darko Sagrak.

Vranicki, P. (1987). Historija marksizma. Zagreb: Centar za kulturnu djelatnost.

Vukmanović, S. (1971). Revolucija koja teče. Beograd: Komunist.

\section{Basic Characteristics of the Verdicts of Yugoslav Communist Military Courts in Croatia in 1944 and 1945}

Josip JURČEVIĆ

Institute of Social Sciences Ivo Pilar, Zagreb

The paper is mainly the result of research of several thousands of verdicts of Yugoslav communist military courts. This historical material has so far been unused or little used in scientific research. The main topic of research are the basic characteristics of the verdicts of Yugoslav communist military courts in Croatia in 1944 and 1945. First, the basic structure of the verdicts is presented. Then, characteristics of individual verdicts from different Croatian regions are analysed in detail, and in the conclusion, the main overall features of surviving verdicts are given. This research has also confirmed that Yugoslav military courts in Croatia were revolutionary courts, and that they were part of the repressive system by which the Communist Party of Yugoslavia completed the process of establishing its totalitarian rule. From the individual verdicts it can clearly be seen that the trials at military tribunals were conducted according to ideological criteria and contrary to legal standards. The trials were quick and punishment merciless. Guilt was not proven based on concrete facts, while testimonies and arguments of the defendants were dismissed without consideration, with insults and degrading statements about the accused. Although the Decree on Military Tribunals prescribed the right to counsel for accused persons, the right was not realized by any of the approximately 5200 convicted persons whose verdicts have survived. And among them there were no acquittals.

Keywords: verdicts of Yugoslav communist military courts, Communist repression in Croatia, revolutionary courts, totalitarianism, Decree on Military Tribunals 